\title{
PARTISIPASI MASYARAKAT DALAM MEMBERDAYAKAN WARGA RETARDASI MENTAL DENGAN MODEL ASANTI EMOTAN (STUDI KASUS DI SIDOHARJO JAMBON PONOROGO)
}

\author{
Muhammad Hanif \\ Program Studi Magister Pendidikan IPS, Program Pascasarjana, IKIP PGRI MADIUN \\ Email : muhhanieff@yahoo.com
}

\begin{abstract}
Abstrak
Tujuan penelitian ini adalah menganalisis tingkat, bentuk, dan faktor yang mempengaruhi partisipasi masyarakat dalam pelaksanaan Model Asanti Emotan. Metode penelitian menggunakan kuantitatif deskriptif. Subjek penelitiannya adalah warga masyarakat normal di lingkungan sekitar warga retardasi mental yang diberi perlakuan dan sampelnya ditentukan secara proposional random. Teknik penggumpulan data menggunakan kuesioner dan dokumentasi. Analisis data menggunakan statistik deskriptif. Hasil penelitian menggambarkan bahwa partisipasi masyarakat dalam pelaksanaan Model Asanti Emotan dalam kategori cukup aktif. Bentuk partisipasi masyarakat berupa bantuan tenaga $(96,8 \%)$, harta benda $(15 \%)$, pikiran $(9 \%)$, dan uang $(5 \%)$. Faktor-faktor yang mempengaruhi partisipasi masyarakat dimulai dari rangking tertinggi yaitu membudayanya adat gotong-royong, keyakinan warga retardasi mental sebagai ujian, perilaku tokoh masyarakat, pengetahuan tentang retardasi mental, mata pencaharian hidup, dan jenis kelamin.
\end{abstract}

Kata kunci:Partisipasi, Model Asanti Emotan, Retardasi Mental

\section{Community Participationin the Implementation of Asanti Emotan Model to Empower Mental Retardation People(A Case Study in Sidoharjo Village, Jambon District, Ponorogo Regency)}

\begin{abstract}
This study, therefore, aims to know the level, form and factors influencing the community participation in the implementation of Asanti Emotan model. The research utilized descriptive quantitative. The subject of the research was the normal people who live in Sidoharjo Village. There were 52 respondents, considered as samples. They were selected by using proportional random. Data were collected through using questionnaires and documentation. The data, then, were analyzed by executing descriptive statistics. The result shows that community participation can be categorized as sufficiently active. The community participation is in the forms of power at $96.8 \%$, personal property at $15 \%$, ideas or thought at $9 \%$ and money at $5 \%$. Thus, some factors that influence the community participation ranging from higher level to lower level, are having accustomed to do things in cooperation, their belief of mental retardation people as a test of life from God, the attitude of distinguished people in the surrounding, the people knowledge of mental retardation, their occupations, and the people' sex.
\end{abstract}

Keywords: Participation, Asanti Emotan Model, Mental Retardation

\section{Pendahuluan}

Desa Sidoharjo Kecamatan Jambon Kabupaten Ponorogo merupakan salah satu desa yang dilabeli sebagai "kampung idiot" karena banyak warganya yang mengalami retardasi mental (tunagrahita). Desa lain yang dilabeli kampung idiot yaitu Desa Krebet Kecamatan Jambon, Desa Karangpatihan dan Pandak Kecamatan Balong, namun jumlahnya tidak sebanyak di Desa Sidoharjo. Jumlah 
warga retardasi mental Desa Sidoharjo sebanyak 138 atau $2,20 \%$ dari jumlah penduduk (6.265 orang).

Sebutan desa-desa di atas sebagai kampung idiot tidaklah tepat karena tidak semua orang yang mengalami retardasi mental adalah idiot, dan tidak semua warga yang cacat adalah mengalami retardasi mental. Dari penelitian sebelumnya ditemukan bahwa selain warga retardasi mental terdapat juga warga yang mengalami kecacatan lain, diantaranya cacat fisik dan sakit jiwa (Hanif dan Afifah,2014). Mereka itu dikategorikan sebagai Orang Dengan Kecacatan (ODK) dengan rincian seperti tercantum dalam tabel 1di bawah ini.

Tabel 1. Data Jumlah Orang Dalam Kecacatan dan Retardasi Mental Desa Sidoharjo

\begin{tabular}{|c|c|c|c|c|c|c|}
\hline \multicolumn{6}{|c|}{ Jenis Kecacatan, Orang } & \multirow[b]{2}{*}{ Jumlah } \\
\hline $\begin{array}{c}\text { Retardasi } \\
\text { Mental }\end{array}$ & $\begin{array}{c}\text { Tuna } \\
\text { Daksa }\end{array}$ & $\begin{array}{c}\text { Tuna } \\
\text { Rungu }\end{array}$ & $\begin{array}{c}\text { Tuna } \\
\text { Wicara }\end{array}$ & $\begin{array}{l}\text { Cacat Pisik- } \\
\text { Lumpuh }\end{array}$ & $\begin{array}{c}\text { Gila/ } \\
\text { Stress }\end{array}$ & \\
\hline 138 & 5 & 9 & 3 & 4 & 5 & 164 \\
\hline
\end{tabular}

(Sumber: Hasil pendataan peneliti bersama FSB, Februari 2015)

Hanif dan Asri (2014) juga menyampaikan bahwa banyak warga yang mengalami retardasi mental di Desa Sidoharjo mulai terjadi 1970-an. Hal tersebut disebabkan oleh berbagai faktor, antara lain; gizi buruk, sarana prasarana dan pelayanan kesehatan yang tidak memadai, air tanah yang dikonsumsi sangat rendah kadar yodiumnya, dan ada juga yang berpendapat kejadian ini karena kutukan.

Dalam kehidupan bersama dengan lingkungan sosial yang diwarnai banyaknya orang yang mengalami retardasi mental tersebut, keluarga dan masyarakat di lingkungan sekitar pada umumnya tidak menyembunyikan, tidak menutupi kondisi warga retardasi mental. Mereka memberi bantuan (pangan, sandang, dan papan), namun belum memfasilitasi warga retardasi mental untuk mengembangkan diri dan mendorong beradaptasi dengan lingkungan(Hanif dan Asri,2014). Hal ini disebabkan oleh banyak orangtua/keluarga dan warga masyarakat di lingkungan sekitar yang belum memiliki pengetahuan dan pemahaman yang memadai tentang penanganan orang retardasi mental. Sehingga orangtua / keluarga dan warga masyarakat walaupun menerima warga retardasi mental tetapi kesannya lebih pada "pembiaran". Oleh karena itu Hanif dan Afifah (2015) dikembangkan Model Asanti Emotan agar upaya pemberdayaan lebih sistematis, terstruktur, dan terprogram sehingga warga retardasi mental lebih berdaya dan mandiri.

Model Asanti Emotan merupakan serangkaian bentuk kegiatan untuk membantu orang retardasi mental dalam mengembangkan kehidupan pribadi, kehidupan keluarga, dan kehidupan sosialnya melalui pembiASAN, pengerTIan, pEMOdelan, dan penguaTAN. Model ini dikembangkan dengan merujuk pada teori perilaku Skinner, teori perilaku Thorndike, dan teori perilaku Bandura. Model Asanti Emotan sudah diujicobakan dan hasilnya dapat meningkatkan kemampuan warga retardasi menjalankan aktivitas pribadi, keluarga, dan sosial (Hanif dan Afifah,2015). Mengingat implementasi model ini melibatkan warga masyarakat di lingkungan sekitarnya, maka keberhasilan uji coba tersebut berkait dengan keikutsertaan/partisipasi masyarakat.Untuk itu menarik dan perlu diteliti dengan tujuan untuk menganalisis dan mendeskripsikan tingkat partisipasi masyarakat dalam pelaksanaan Model Asanti Emotan, bentuk-bentuk partisipasinya, dan faktor-faktor yang mempengaruhi partisipasinya.Penelitian urgen dilaksanakan dengan harapan hasilnya dapat dijadikan sumber daya gugah dalam meningkatkan partisipasi masyarakat sehingga warga retardasi mental lebih berdaya dan mandiri. 
Avaliable online at http://e-journal.ikippgrimadiun.ac.id/index.php/gulawentah

Partisipasi masyarakat dimaknai sebagai keikutsertaan sekelompok anggota masyarakat dalam pembangunan diri, kehidupan, dan lingkungan (Mikkelsen,2003). Makna tersebut selaras dengan pendapat Isbandi (dalam Deviyanti, 2013) bahwa partisipasi masyarakat merupakan keikutsertaan masyarakat dalam proses pengidentifikasian masalah dan potensi yang ada di masyarakat, pemilihan dan pengambilan keputusan tentang alternatif solusi untuk menangani masalah, pelaksanaan upaya mengatasi masalah, dan keterlibatan masyarakat dalam proses mengevaluasi perubahan yang terjadi.

Keikutsertaan anggota masyarakat tersebut merupakan akibat dari hubungan diantara warga masyarakat tentang kehidupannya. Verhangen (dalam Theresia dkk, 2014:197) mengungkapkan bahwa partisipasi sebagai suatu bentuk hubungan khusus berkaitan dengan, kewenangan, tanggung jawab, dan manfaat. Tumbuhnya partisipasi dilandasi oleh adanya kesadaran yang dimiliki anggota masyarakat mengenai kondisi yang tidak memuaskan dan harus diperbaiki, kondisi tersebut dapat diperbaiki melalui kegiatan masyarakat, kemampuan untuk ikutserta, dan adanya kepercayaan diri bahwa konstribusinya bermanfaat bagi kegiatan tersebut. Dalam konteks pemberdayaan warga retardasi mental diartikan sebagai perwujudan kesadaran, kepedulian, dan tanggung jawab sosial untuk memberdayakan dan/atau memandirikan mereka yang mengalami retardasi mental.

Yadav (dalam Theresia,2014) menyampaikan macam-macam partisipasi masyarakat dalam pembangunan, yaitu partisipasi dalam; (1) pengambilan keputusan, pelaksanaan kegiatan, pemantauan dan evaluasi, dan pemanfaatan hasil. Sedangkan bentuk-bentuk partisipasi menurut Holil (dalam Deviyanti, 2013) n berupa: (a) buah pikiran, (b) tenaga, (c) uang, (d) harta benda. Sedangkan dilihat dari derajat kesukarelaannya, partisipasi dapat dijenjang, yaitu; (1) partisipasi spontan, yaitu peranserta karena motivasi instriksik, (2) partisipasi terinduksi, yaitu karena terinduksi oleh adanya motivasi ekstrinsik (3) partisipasi tertekan, yaitu peranserta karena adanya tekanan oleh kebiasaan, alasan sosialekonomi, dan peraturan (Dusseldorp, 1981).

Timbulnya partisipasi masyarakat menurut Slamet (1994:97) didukung faktor utama yaitu; (1) adanya kesempatan yang diberikan kepada masyarakat untuk berpartisipasi, (2) adanyanya kemauan masyarakat untuk berpartisipasi, dan (3) adanya kemampuan masyarakat untuk berpartisipasi. Sedangkan faktor-faktor yang mempengaruhi partisipasi masyarakat dapat berasal dari faktor internal maupun eksternal. Faktor internal yaitu kemampuan dan kesediaan masyarakat. Hal ini berkaitan dengan ciri-ciri sosiologis seperti umur, jenis kelamin, pengetahuan, pekerjaan dan penghasilan. Sedangkan faktor eksternal yaitu stakeholder yang mempunyai kepentingan dan pengaruh terhadap program ini.

Retardasi mental sering dipadankan dengan istilah lemah pikiran (feeble-minded), terbelakang mental (mentally retarded), dungu (idiot), gangguan intelektual, dan lain sebagainya. Dalam psikologi klinis, orang yang mengalami retardasi mental adalah kelainan atau kelemahan jiwa dengan inteligensi yang kurang. Biasanya terdapat perkembangan mental yang kurang secara keseluruhan tetapi gejala yang utama adalah intelegensi yang terbelakang (Maramis, 2005: 386).Pendapat serupa disampaikan American Asociation on Mental Deficiency/AAMD, retardasi mental yaitu kondisi fungsi intelektual umum di bawah rata-rata (Kaplan dkk, 1997:673).Hal tersebut ditegaskan Santrock (2010: 224-225)danDurant dan Barlow (2007: 305-306) bahwa retardasi mental adalah kondisiyangditandai dengan rendahnya kecerdasan, sulit bersosialisasi, dan sulitberadaptasi dalam kehidupan seharihari.

Nevid, Rathus, dan Greene (2003:149150) mengklasifikasi retardasi mental berdasarkan Intelligence Quotient) menjadi 3, yaitu; (1) debil, IQ:70-90 adalah retardasi mental ringan yang tingkatan intelegensi 
setara dengan anak normal berusia 7-12 tahun, bersifat educable,.(2) imbecil, IQ:5070adalah retardasi mental sedang yang tingkatan intelegensinya setara dengan anakanak normal usia 3-7 tahun, kemampuan membentuk konsep amat terbatas, namun trainable, (3) Idiot, IQ:0-25 adalah retardasi mental berat yang tingkatan intelegensi setara dengan anak normal berusia 1-3 tahun, bersifat tergantungkarena tidak mampu hidup tanpa pertolongan orang lain.IQ ini bukan merupakan satu-satunya patokan yang dapat digunakan untuk menentukan berat ringannya retardasi mental tetapi juga bisa mendasarkan pada penilaian keterampilan spesifik dan perilaku adaptif dan hasil tes psikomotorik. Dengan demikian retardasi mental merupakan hasil proses patologik di dalam otak yang menyebabkan keterbatasan terhadap intelektualitas dan fungsi adaptif.

Pemberdayaan mengandung dua pengertian yaitu (1) to give power outhority yang berarti sebagai upaya memberi kekuasaan, mengalihkan kekuatan atau mendelegasikan otoritas ke pihak lain, (2) to give ability to or enable yang berarti sebagai upaya untuk memberikan kemampuan atau keberdayaan (Prijono dan Pranata, 1996:3). Parson (1994) juga menyampaikan pendapat serupa yaitu sebuah proses agar seseorang atau sekelompok orang menjadi cukup kuat untuk berpartisipasi dalam berbagai pengontrolan dan mempengaruhi kejadiankejadian serta lembaga-lembaga yang mepengaruhinya.

Pemberdayaan masyarakat pada hakikatnya merupakan sebuah proses dan tujuan. Pemberdayaan sebagai proses adalah serangkaian kegiatan untuk memperkuat kekuasaan atau keberdayaan kelompok lemah dalam masyarakat. Sedangkan pemberdayaan menunjuk pada keadaan atau hasil yang ingin dicapai yaitu masyarakat berdaya Suharto (2009:59-60). Dengan demikian yang dimaksud pemberdayaan warga retardasi mental adalah sebuah rangkaian proses kegiatan untuk memberdayakan warga retardasi mental agar mampu dan kuat menjalankan aktivitas hidupnya dengan tetap memperkuat potensi atau daya yang dimilikinya.

\section{Metode Penelitian}

Penelitian ini mengunakan pendekatan kuantitatif deskriptif. Subjek penelitiannya adalah warga masyarakat normal yang berada di lingkungan sekitar atau tetangga warga retardasi mental yang diberi perlakuan dengan model. Sampel penelitian ditentukan dengan teknik porposional random. Adapun jumlah respondennya 52 orang dengan pertimbangan pada ujicoba tahun 2014 ditentukan 13 orang sampel dan masing-masing sampel warga retardasi mental diwakili 4 orang tetangga.

Untuk mengukur tingkat partisipasi dan bentuk partisipasi menggunakan rating scale.Skala ini menurut Sugiyono (2012), responden tidak akan menjawab salah satu jawaban kualitatif yang tersedia tetapi menjawab salah satu jawaban kuantitatif yang disediakan dan hasilnya ditabulasikan kemudian ditafsirkan dalam pengertian kualitatif. Sedangkan faktor-faktor yang mempengaruhi dijaring dalam rangking ordinal. Teknik pengambilan data menggunakan kuesioner dan dokumentasi.Data yang diperoleh kemudian dianalisis dengan statistik deskriptif.

\section{Hasil dan Pembahasan}

\section{Gambaran Singkat Tentang Desa Sidoharjo dan Warga Retardasi Mental}

Desa Sidoharjo merupakan desa hasil pemekaran wilayah Desa Krebet Kecamatan Jambon. Pemekaran desa ini bertujuan untuk mengintensifkan dan mengefektifkan pembangunan. Desa Krebet sebelum pemekaran memiliki luas wilayah lebih dari $25 \mathrm{Km}^{2}$, dibagi dalam 9 dukuh, dan jumlah penduduk yang mencapai 12 ribu jiwa. Kondisi tersebut tidak seimbang dengan daya dukungnya. Sarana-prasarana dan sumberdaya yang tersedia tidak mampu menjangkau secara optimal beberapa dukuh di wilayah Selatan. Untuk mengatasi berbagai masalah tersebut di atas, pemerintahan desa Krebet berupaya mencari alternatif pemecahannya yaitu perlu ada pemekaran 
atau pemecahan Desa Krebet, Desa Krebet dimekarkan menjadi 2 desa, wilayah desa pemekaran mencakup 3 dukuh, yaitu Dukuh Klitik, Dukuh Karangsengon dan Dukuh Sidowayah, dan desa pemekaran diberi nama Desa Sidoharjo

Luas wilayah Desa Sidoharjo tergolong luas yaitu 1.219, 84 hektar namun tidak subur, $60 \%$ dari luas wilayah dataran dan $40 \%$ perbukitan/pegunungan, hanya memiliki satu akses jalan masuk, lantaran sisi-sisi jalannya tertutup oleh perbukitan. Hanya ada satu jalan utama setelah melewati sawah, ladang dan perbukitan. Jalan menyempit saat memasuki desa tersebut. Umumnya, jalan terbagi tiga tipe; aspal, makadam dan paping, serta tanah dengan berbagai tanjakan dan turunan khas daerah pegunungan. Jumlah penduduk Desa Sidoharjo 6.265 orang dengan mata pencaharian mayoritas sebagai tani dan buruh tani.

Penduduk Desa Sidoharjo banyak yang mengalami retardasi mental terjadi mulai tahun 1970-an. Hal tersebut disebabkan oleh berbagai faktor, antara lain; (1) kemiskinan dan gizi buruk, (2) fasilitas kesehatan yang tidak memadai, (3) air tanah yang dikonsumsi tidak mengandung kadar yodium yang cukup, dan (4) "kutukan" (Hanif dan Asri,2014). Warga retardasi mental berdasarkan tingkat keterampilan dan adaptifnya dapat diklasifikasikan pada tabel 2 .

Tabel 2 Data Orang Retardasi Mental Berdasarkan Kategori Retardasi Mental

\begin{tabular}{lcccc}
\hline \multirow{2}{*}{ Kategori Retardasi Mental } & \multicolumn{3}{c}{ Jenis Kelas, Orang } & \multirow{2}{*}{ Jumlah } \\
\cline { 2 - 4 } & $\mathrm{L}$ & $\mathrm{P}$ & \\
\hline Debil & 60 & 35 & 95 \\
Imbesil & 10 & 20 & 30 \\
Idiot & 6 & 7 & 13 \\
\hline & Sub Jumlah & 76 & 62 & \\
\hline & Jumlah & \multicolumn{2}{c}{138} & 138 \\
\hline
\end{tabular}

(Sumber: Hasil pencataan peneliti bersama FSB Tahun 2015)

\section{Model Asanti Emotan}

Model pemberdayaan Asanti Emotan merupakan serangkaian bentuk kegiatan untuk membantu orang retardasi mental dalam mengembangkan kehidupan pribadi, kehidupan keluarga, dan sosialnya melalui pembiasaan, pengertian, pemodelan, dan penguatan. Model Asanti Emotan memfasilitasi dan mengoptimalisasi warga retardasi mental secara individu maupun kelompok, sesuai dengan kebutuhan, potensi, bakat, minat, perkembangan, kondisi, dan peluang-peluang yang dimilikinya.

Nama Asanti Emotan merupakan akronim dari prinsip-prinsip model ini yaitu pembiASAN, pengerTIan, pEMOdelan, dan penguaTAN (conditioning, insight, modelling, and reinforcement). Asas-asas pemberdayaan melalui model ini meliputi; kesukarelaan, keterbukaan, kemandirian, kedinamisan, keterpaduan, kenormatifan, dan tut wuri handayani. Fungsi model antara lain; (1) Pemahaman yaitu untuk membantu warga retardasi mental memahami diri, keluarga, dan lingkungannya, (2) Pencegahan yaitu untuk membantu warga retardasi mental mampu mencegah atau menghindarkan diri dari berbagai permasalahan yang dapat menghambat perkembangan dirinya, (3) Pengentasan yaitu untuk membantu warga retardasi mental mengatasi masalah-masalah terutama keterbatasan yang dialaminya, dan (4) Pengembangan yaitu untuk membantu warga retardasi mental menumbuhkembangkan potensi yang dimilikinya.

Model Asanti Emotan dapat dilaksanakan dalam berbagai bentuk kegiatan, antara lain; (1) Individu yaitu bentuk kegiatan pemberdayaan yang membantu orang retardasi mental secara perorangan, (2) Kelompok yaitu bentuk kegiatan pemberdayaan yang membantu sejumlah orang retardasi mental melalui suasana dinamika kelompok, (3) Lapangan yaitu bentuk kegiatan pemberdayaan yang membantu seorang atau sejumlah orang 
melalui kegiatan lapangan. Model ini dapat dilaksana oleh orang tua/keluarga, tokoh masyarakat di lingkungan sekitar, secara sendiri atau bersama. Adapun sintaknya dapat dilihat pada gambar 1 .

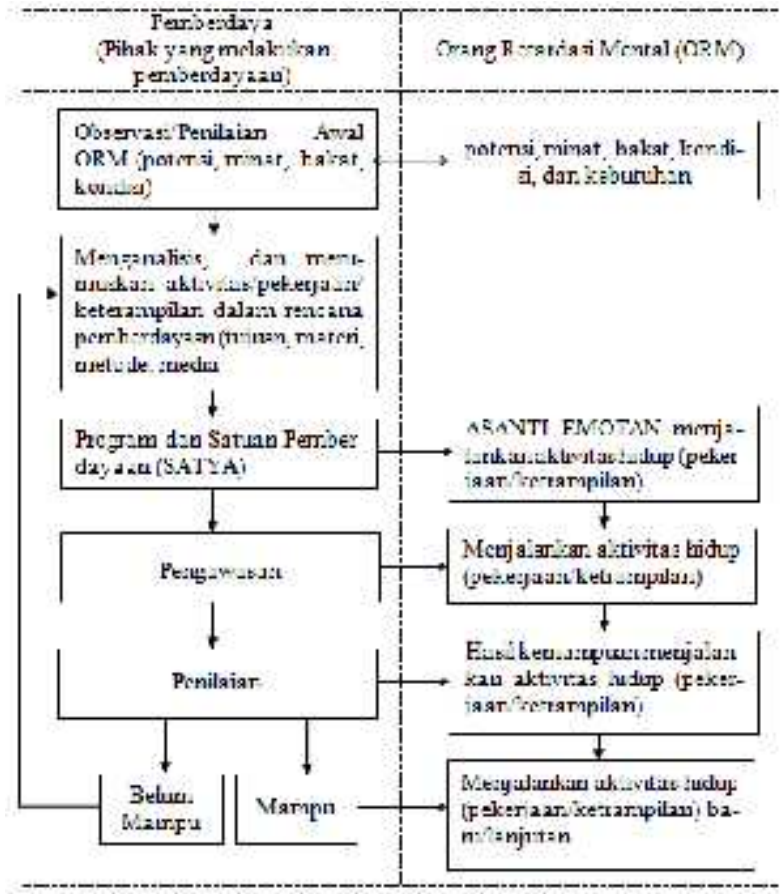

Gambar 1 Sintak Pelaksanaan Model Asanti Emotan

(Hanif dan Afifah, 2015)

Dalam pelaksanaan pemberdayaan dengan Model Asanti Emotan ini, perlakuan terhadap orang retardasi mental dimulai dari pembiasaan kemudian dilanjutkan dengan pemberian pengertian, pemodelan, dan pemberian penguatan. Namun dalam kondisi tertentu karena situasi dan kondisi, maka pengkondisian, pengertian dan pemodelan dapat dilaksanakan secara ulang-alik tergantung pada situasi dan kondisi subyek.

\section{Partisipasi Masyarakat Dalam Pelaksanaan Model Asanti Emotan}

Reponden penelitian ini berjumlah 52 orang dengan karakteristik sebagai berikut:

1) Berdasarkan jenis kelamin: 32 lakilaki dan 20 perempuan

2) Berdasarkan pendidikan: SD 34 orang, SLTP 15 orang, SLTA 3 orang

3) Berdasarkan pekerjaan: PNS 2 orang, Perangkat desa 4 orang, Petani 25, Tukang bangunan 13 orang, Swasta 8 orang

4) Berdasarkan agama: Islam 39 orang
Data tingkat partisipasi masyarakat dalam pelaksanaan Model Asanti Emotan sebagai berikut:

Tingkat partisipasi masyarakat dalam perencanaan program

Kegiatan dalam perencanaan program meliputi observasi, analisis kebutuhan, potensi, bakat, minat, perkembangan, kondisi, peluang-peluang yang dimiliki orang retardasi mental yang akan diberdayakan, dan menyusun program kegiatan pemberdayaan. Program pemberdayaan yang direncanakan dalam bentuk satuan pemberdayaan yang akan dilaksanakan sesuai dengan sasaran, subtansi, jenis kegiatan, waktu, tempat, dan pihak-pihak terkait.

Untuk mendapatkan data tingkat partisipasi masyarakat dalam kegiatan tersebut di atas digali melalui 10 pertanyaan ukuran dengan interval jawaban 5 (SA: sangat aktif/selalu), 4 (A: aktif/sering), 3 (CA: cukup aktif/kadang-kadang), 2 (TA: tidak aktif/hampir tidak pernah), 1 (STA: sangat 
Avaliable online at http://e-journal.ikippgrimadiun.ac.id/index.php/gulawentah

tidak aktif/tidak pernah). Jumlah skor ideal atau kriterium 2.600. Jumlah skor hasil pengumpulan data dari 52 responden tentang keikutsertaan dalam kegiatan perencanaan program ditabulasi dan jumlah skor yang

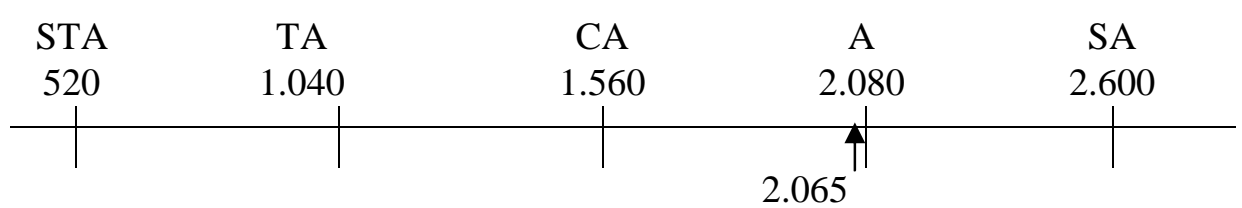

Nilai 2.015 termasuk dalam kategori interval cukup aktif dan sangat aktif tapi lebih mendekati aktif.

\section{Tingkat partisipasi masyarakat dalam} pelaksanaan program

Kegiatan dalam melaksanakan program yaitu memberi perlakuan orang retardasi mental dengan ASANTI EMOTAN dalam menjalankan aktivitas pekerjaan atau keterampilan tertentu. Selain itu juga melakukan pendampingan dalam kurun waktu yang ditetapkan terhadap orang retardasi mental yang diberi perlakuan dalam menjalankan aktivitas hidup, menjalankan pekerjaan, atau melakukan pekerjaan keterampilan tertentu sebagaimana yang diharapkan dari program.

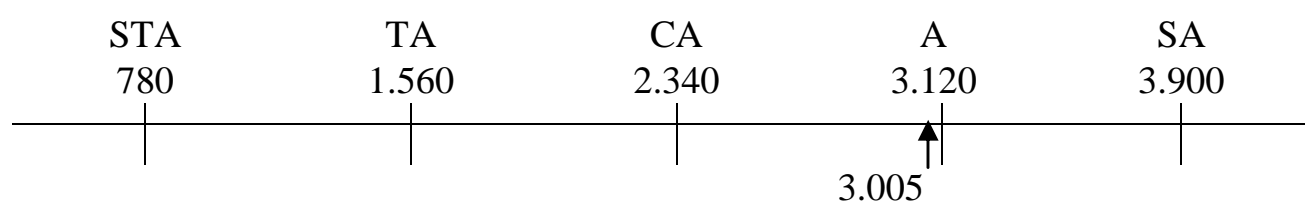

Nilai 3.005 termasuk dalam kategori interval cukup aktif dan aktif tapi lebih mendekati aktif.

\section{Tingkat partisipasi masyarakat dalam evaluasi pelaksanaan program}

Kegiatan dalam evaluasi pelaksanakan program meliputi kegiatan penilaian proses mulai dari penilaian kemampuan awal, pelaksanaan, dan setelah pemberian perlakuan Asanti Emotan. Jika orang retardasi mental belum mampu menjalankan aktivitas hidup sebagaimana yang ditentukan, maka kegiatan diulang. Sedangkan orang yang sudah mampu

\subsection{5} atau lanjutan. diperoleh 2.065. Dengan demikian tingkat partisipasi 52 responden yaitu $(2.065: 2.600) \times 100 \%=80 \%$ dari kriteria yang ditetapkan. Hal ini secara kontinum dapat dibuat kategori sebagai berikut:

Untuk mendapatkan data tingkat partisipasi masyarakat dalam pelaksanaan program model pemberdayaan warga retardasi mental di atas digali melalui 15 pertanyaan ukuran dengan interval jawaban sama dengan kriterium sebelumnya. Jumlah skor kriterium 3.900. Jumlah skor hasil pengumpulan data dari 52 responden tentang keikutsertaan dalam kegiatan perencanaan program ditabulasi dan jumlah skor yang diperoleh 3.005 . Dengan demikian tingkat partisipasi 52 responden yaitu $(3.005: 3.900) \times 100 \%=77 \%$ dari kriteria yang ditetapkan. Hal ini secara kontinum dapat dibuat kategori sebagai berikut:

menjalankan aktivitas hidup sebagaimana yang ditentukan, maka diberi kegiatan baru

Untuk mendapatkan data tingkat partisipasi masyarakat dalam evaluasi pelaksanaan program pemberdayaan warga mental di atas digali melalui 10 pertanyaan ukuran dengan interval jawaban sama dengan kriterium sebelumnya. Jumlah skor kriterium 2.600. Jumlah skor hasil pengumpulan data dari 52 responden tentang keikutsertaan dalam kegiatan evaluasi ditabulasi dan jumlah skor yang diperoleh 2.074 . Dengan demikian tingkat partisipasi 52 responden yaitu $(2.074: 2.600) \times 100 \%=80 \%$ dari kriteria yang 
ditetapkan. Hal ini secara kontinum dapat dibuat kategori sebagai berikut:

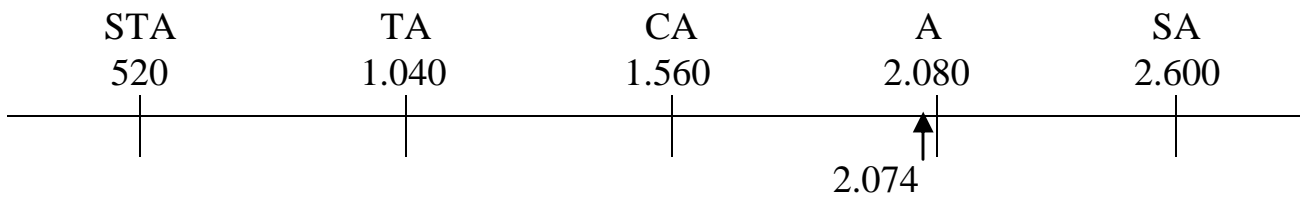

Nilai 2.074 termasuk dalam kategori interval cukup aktif dan aktif tapi lebih mendekati aktif.

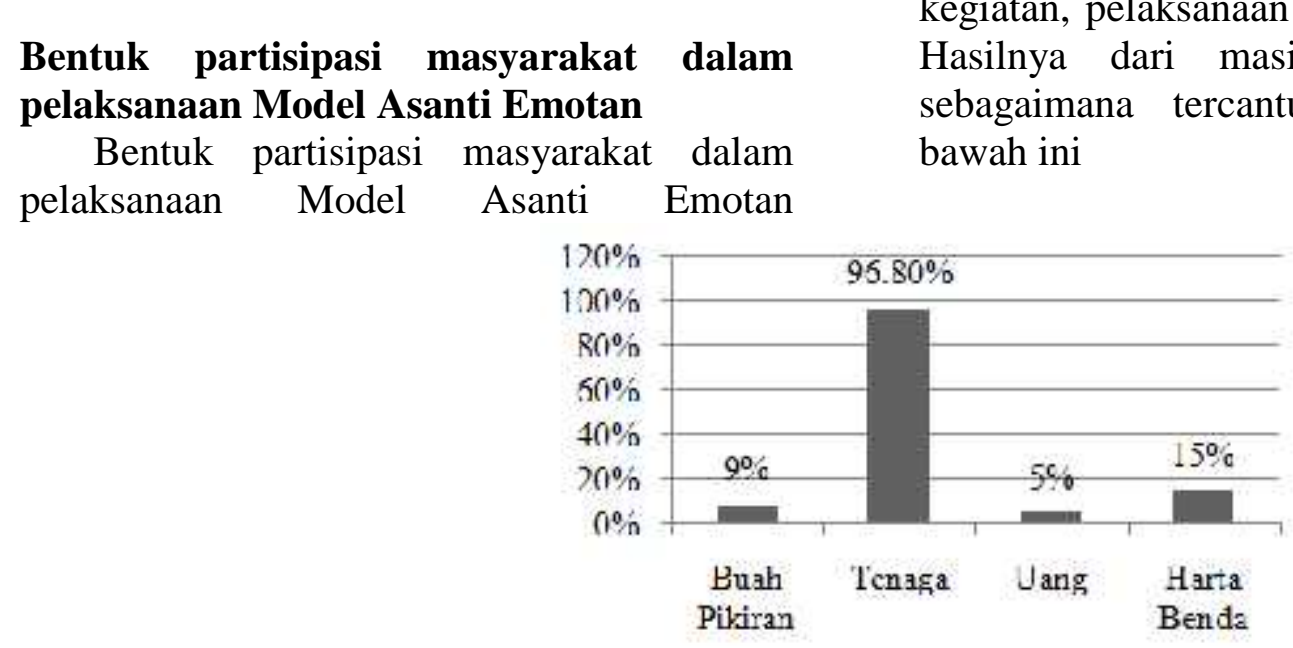

Gambar2. Grafik Bentuk Partisipasi Masyarakat

Gambar 2. di atas menunjukkan bahwa bentuk partisipasi masyarakat yang paling dominan adalah bantuan tenaga kemudian disusul bantuan harta benda, buah pikiran, dan uang.

\section{Faktor-faktor yang mempengaruhi partisipasi masyarakat dalam melaksanakan Model Asanti Emotan}

diwujudkan dalam berbagai bentuk bantuan yaitu; buah pikiran, tenaga, uang, dan harta benda dalam penyusunan rencana program kegiatan, pelaksanaan kegiatan, dan evaluasi. Hasilnya dari masing-masing komponen sebagaimana tercantum pada gambar di bawah ini

Tabel 3. Rangking Faktor-faktor yang Mempengaruhi Partisipasi Masyarakat

\begin{tabular}{clcc}
\hline \multirow{2}{*}{ No } & \multicolumn{2}{|}{ Faktor-faktor } & \multicolumn{2}{c}{ Jawaban Responden } \\
\cline { 3 - 4 } & & Jumlah & \multicolumn{1}{c}{$\%$} \\
\hline 1 & Adat gotong-royong & 52 & 34,21 \\
2 & Keyakinan-religi & 38 & 25,00 \\
3 & Perilaku tokoh masyarakat & 25 & 16,45 \\
4 & Pendidikan-pengetahuan & 18 & 11,84 \\
5 & Mata pencaharian hidup & 15 & 9.87 \\
6 & Jenis kelamin & 4 & 2,63 \\
\hline \multicolumn{2}{r}{ Jumlah } & 152 & 100 \\
\hline
\end{tabular}


Avaliable online at http://e-journal.ikippgrimadiun.ac.id/index.php/gulawentah

Dari para responden diperoleh keterangan bahwa masyarakat memiliki ikatan perasaan batin yang kuat sesama warga desa yang diwujudkan dalam gotong royong, tolong menolong, perasaan bersedia untuk berkorban setiap waktu demi masyarakat atau anggota masyarakat termasuk warga retardasi mental. Keyakinan masyarakat bahwa warga retardasi mental merupakan kutukan, sekarang mulai mengalami pergeseran. Masyarakat banyak yang meyakini bahwa warga retardasi mental adalah ujian dari Tuhan yang harus disikapi bersama. Pergeseran sikap dan carapandang tidak lepas dari penjelasan dari tokoh masyarakat, tokoh agama, tokoh pemuda dan teladan darinya yang berusaha membantu warga retardasi mental. Pengetahuan tentang warga retardasi mental masih memiliki potensi yang dapat diberdayakan selain informasi dari para tokoh masyarakat, juga didapat dari para penyuluh dan peneliti. Mata pencaharian hidup yang mayoritas petani dan buruh tani tidak menghalangi langkahnya untuk turut serta walaupun berupa tenaga. Laki-laki dan perempuan berbagi tugas, fungsi, dan tidak membedakannya untuk bersama-sama berpartisipasi dalam kegiatan pemberdayaan warga retardasi mental karena hal tersebut dipandang sebagai tugas dan tanggung jawab bersama.

Faktor-faktor tersebut di atas dalam hubungannya dengan bentuk-bentuk partisipasi masyarakat dalam melaksanaan Model Asanti Emotan terlihat dalam tabel 4 di bawah ini.

Tabel 4. Hubungan Faktor-faktor yang Mempengaruhi dengan Bentuk Partisipasi

\begin{tabular}{clcccc}
\hline \multirow{2}{*}{ No } & \multicolumn{1}{c}{ Faktor } & \multicolumn{4}{c}{ Bentuk Partisipasi } \\
\cline { 3 - 6 } 1 & Adat gotong-royong & - & $\begin{array}{c}\text { Tenaga } \\
(0,038<0,05)\end{array}$ & $\begin{array}{c}\text { Signifikan } \\
(0,042<0,05)\end{array}$ & $\begin{array}{c}\text { Signifikan } \\
(0,039<0,05)\end{array}$ \\
\hline 2 & Keyakinan-religi & $\begin{array}{c}\text { Signifikan } \\
(0,035<0,05)\end{array}$ & $\begin{array}{c}\text { Signifikan } \\
(0,04<0,05)\end{array}$ & - & $\begin{array}{c}\text { Signifikan } \\
(0,041<0,05)\end{array}$ \\
\hline 3 & Perilaku tokoh masyarakat & $\begin{array}{c}\text { Signifikan } \\
(0,045<0,05)\end{array}$ & $\begin{array}{c}\text { Signifikan } \\
(0,038<0,05)\end{array}$ & - & $\begin{array}{c}\text { Sinifikan } \\
(0,038<0,05)\end{array}$ \\
\hline 4 & Pendidikan-pegetahuan & $\begin{array}{c}\text { Signifikan } \\
(0,042<-0,05)\end{array}$ & - & - & - \\
\hline 5 & Mata pencaharian hidup & - & $\begin{array}{c}\text { Signifikan } \\
(0,043<0,05)\end{array}$ & $\begin{array}{c}\text { Tidak Signifikan } \\
(0,14>0,05)\end{array}$ & $\begin{array}{c}\text { Signifikan } \\
(0,040>0,05)\end{array}$ \\
\hline 6 & Jenis kelamin & - & $\begin{array}{c}\text { Tidak Signifikan } \\
(0,15>0,05)\end{array}$ & - & - \\
\hline
\end{tabular}

Tabel di atas merupakan hasil analisis faktor-faktor yang mempengaruhi partisipasi dengan bentuk-bentuk partisipasi yang membutuhkan eksplorasi pemikiran yang dalam (buah pikiran) dan tidak membutuhkan eksplorasi pemikiran yang dalam (tenaga, uang, dan harta benda).

Hasil penelitian di atas menunjukkan bahwa partisipasi masyarakat dalam pelaksanaan Model Asanti Emotan dalam kategori cukup aktif, baik dalam kegiatan perencanaan program, pelaksanaan program, maupun evaluasi. Kecukupaktifan masyarakat dalam melaksanakan model menggambarkan tumbuhnya kesadaran mengenai kondisi yang tidak memuaskan dan berusaha memperbaiki melalui kegiatan kemasyarakatan. Hal ini sejalan dengan pendapat Yadav (dalam Theresia dkk,2014) dan Isbandi (dalam Deviyanti,2013) bahwa partisipasi masyarakat merupakan keikutsertaan masyarakat dalam proses pengidentifikasian masalah dan potensi yang ada di masyarakat, pemilihan dan pengambilan keputusan tentang alternatif solusi untuk menangani masalah, pelaksanaan upaya mengatasi masalah, dan keterlibatan masyarakat dalam proses mengevaluasi perubahan yang terjadi.

Bentuk-bentuk partisipasi masyarakat dalam melaksanakan Model Asanti Emotan selaras dengan pendapat Holi (dalam Deviyanti,2014) yaitu bentuk bantuan pemikiran, tenaga, uang dan harta benda. Bantuan tenaga menjadi wujud bantuan yang 
dominan karena tenaga merupakan bentuk partisipasi yang langsung dapat diberikan pada saat itu juga tanpa membutuhkan waktu yang lama dan tidak membutuhkan eksplorasi pemikiran yang mendalam. Sedangkan bentuk partisipasi yang paling kecil adalah bantuan uang. Partisipasi masyarakat tersebut tumbuh karena masyarakat mempunyai kemauan dan kemampuan untuk berpartisipasi walaupun konstribusinya relatif tidak sama sehingga bantuannya yang dominan adalah tenaga. Hal dipengaruhi oleh berbagai faktor dan dengan urutan berdasarkan rangkingnya yaitu; (1) masih membudaya adat gotong royong, (2) keyakinan banyaknya warga retardasi mental merupakan ujian, (3) perilaku tokoh masyarakat, (4) pengetahuan bahwa orang retardasi mental masih memiliki potensi yang dapat diberdayakan, (5) jenis kelamin, dan (6) Mata pencaharian hidup atau pekerjaan. Bila ditelaah lebih dari sudut pandang derajat kesukarelaannya maka partisipasi masyarakat termasuk partisipasi spontan dan terinduksi. Dusseldorp (1981) menyampaikan bahwa partisipasi spontan merupakan partisipasi yang tumbuh karena dorongan dari dalam (instrinsik) berupa pemahaman, penghayatan dan keyakinan. Sedangkan partisipasi terinduksi yaitu partisipasi yang tumbuh karena terinduksi oleh adanya motivasi ekstrinsik dalam konteks ini adalah perilaku tokoh masyarakat.

Faktor gotong-royong menjadi faktor tertinggi yang mempengaruhi partisipasi masyarakat dan berhubungan signifikan dengan bentuk bantuannya. Hal ini terjadi karena masyarakat Desa Sidoharjo masih kental dengan nilai-nilai gotong-royong dan tolong menolong. Interelasi sosial tersebut sebagai sesuatu yang kas dari masyarakat desa seperti yang disampaikan Setiadi dan Kolip (2011:839-840) bahwa masyarakat pedesaan memiliki ikatan perasaan batin yang kuat sesama antar warga desa. Warga masyarakat merasa menjadi bagian yang tidak terpisahkan dan bersedia untuk berkorban demi kepentingan bersama di dalam masyarakat.Aspek ini melembaga menjadi sistem budaya dan memiliki peran sebagai;
(1) pedoman hubungan antar manusia atau kelompoknya, (2) pembimbing kehidupan dan penghidupan manusia, (3) petunjuk-petunjuk tentang bagaimana manusia harus bertindak dan berperilaku dalam pergaulan.

Faktor keyakinan menjadi faktor urutan kedua yang mempengaruhi partisipasi masyarakat karena masyarakat tergolong religius dan berhubungan signifikan dengan bentuk partisipasinya. Segala sesuatu hampir selalu dikaitan dengan Tuhan termasuk banyaknya warga yang mengalami retardasi mental. Mereka memiliki keyakinan bahwa banyak warga retardasi mental bukan musibah tetapi ujian dari Tuhan. Hasil ini sejalan dengan penelitian Hendriani dkk (2006) yang menemukan perilaku penerimaan warga retardasi mental dipengaruhi oleh adanya suatu keyakinan bahwa anak adalah titipan Tuhan. Keyakinan-keyakinan tersebut menurut Azwar (2011:12) berpengaruh pada sikap dan perilaku tertentu, pada normanorma, dan pada kontrol perilaku dan apabila berinteraksi menjadi determinan bagi intensi yang pada gilirannya akan membentuk perilaku partisipatif.

Faktor perilaku tokoh masyarakat, tokoh agama, dan tokoh pemuda yang peduli warga retardasi mental menginduksi masyarakat berpartisipasi melaksanakan Model Asanti Emotan. Realita ini lazim terjadi pada masyarakat pedesaan yang lekat dengan budaya paternalistik.Hal tersebut sejalan dengan pendapat Setiadi dan Kolip (2011:851) bahwa masyarakat paternalistik cenderung menerima pandangan, sikap, dan tindakan tertentu dari orang yang "dituakan" dipatronkan, dan dijadikan panutan.Peran tokoh dalam partisipasi masyarakat juga sesuai dengan teori interaksi sosial. Teori ini menempatkan individu sebagai pihak yang aktif dalam menetapkan perilaku sosial dan membangun harapan-harapan sosial. Interaksi sosial dinyatakan juga sebagai faktor yang mempengaruhi perilaku sosial (Walgito,2011). Dengan demikian benar yang disampaikan Bandura (dalam Jarvis, 2000:29) bahwa pengaruh utama terhadap 
perilaku adalah hasil dari perilaku meniru perilaku model.

Faktor pendidikan juga ikut serta mempengaruhi partisipasi masyarakat dan signifikan dengan bentuk bantuannya.Pendidikan membuat masyarakat mengetahui dan memahami retardasi mental bukan penyakit dan orang retardasi mental masih memiliki potensi yang dapat diberdayakan. Partisipasi masyarakat tidak hanya sekadar warisan dari keluarga, tetapi juga produk masyarakat sebagai hasil dari proses belajar yang menghasilkan pengetahuan dan penghayatan. Middlebrook (dalam Azwar,2011:31) mengatakan bahwa tidak adanya pengalaman sama sekali dengan suatu objek perilaku sosial cenderung akan bertindak negatif.Dengan demikian peningkatan pendidikan membawa perubahan-perubahan nilai.Melalui perubahan nilai yang positif, warga masyarakat memiliki pandangan positif dan mempengaruhi penghayatan terhadap stimulus (warga retardasi mental) kemudian membentuk partisipasi masyarakat.

Faktor mata pencaharian hidup termasuk faktor yang mempengaruhi partisipasi masyarakat. Tingkat pekerjaan tertentu lebih meluangkan atau bahkan tidak meluangkan waktunya untuk berpartisipasi dalam suatu kegiatan kemasyarakat. Hal ini sejalan dengan pendapatnya Slamet (1993) bahwa pekerjaan atau mata pencaharian mempengaruhi bentuk partisipasi karena mata pencaharian berhubungan dengan waktu luang seseorang dan terkait dengan penghasilan yang diperoleh. Faktor ini tidak signifikan dengan bentuk bantuan uang. Kecilnya bantuan yang berwujud uang karena kemampuan ekonomi masyarakat relatif terbatas. Masyarakat desa ini tidak sedikit yang hidup di bawah garis kemiskinan. Dengan garis kemiskinan untuk pedesaan Rp292.961/kapita/bulan (BPS 2014), rumah tangga di desa ini yang hidup di bawah garis kemiskinan 944 rumah tangga atau 56,32\% dari jumlah rumah tangga keseluruhan yaitu 1.676 rumah tangga. Walaupun masyarakat hidup dalam kondisi ekonomi yang tidak begitu menjanjikan tapi masih sangat peduli untuk turut serta membantu warga retardasi mental. Partisipasi masyarakat tersebut membuktikan kebenaran berbagai kajian psikologi kognitif yang menyatakan bahwa pandangan manusia sebagai homo economicus tidak selalu rasional dalam menentukan pilihannya, terkadang manusia dapat pula berfikir tidak rasional dalam menentukan pilihannya seperti yang diungkapkan dalam behavioral economis dan juga dalam constrain theory, dimana manusia selalu diliputi berbagai pilihan yang terkadang dalam menjatuhkan pilihannya bukan lagi berdasarkan untungrugi tetapi berdasarkan pertimbanganpertimbangan sosial, emosi, dan sebagainya (Homans dalam Ritzer,2012).

Faktor jenis kelamin menjadi faktor terendah yang mempengaruhi partisipasi masyarakat dalam memberdayakan warga retardasi mental.Faktor ini juga tidak berhubungan secara signifikan dengan bentuk bantuan tenaga.Hal ini terjadi karena situasi, kondisi, dan tantangan yang dihadapi membutuhkan uluran tangan kedua belah pihak dan mereka menyadarinya.Realita ini sejalan dengan pendapat Setiadi dan Kolip (2011:880) bahwa perempuan dan laki-laki menurut teori gender berbeda.Ibu dalam lingkungan keluarga tugasnya mengatur jalannya rumah tangga dan memelihara anak, sedangkan suami tugas utamanya mencari nafkah tampaknya sudah mengalami pergeseran.

\section{Kesimpulan dan Saran}

Berdasarkan hasil penelitian dan pembahasan penelitian yang telah disampaikan di atas maka dapat disimpulkan bahwa partisipasi masyarakat dalam pelaksanaan Model Asanti Emotan guna memberdayakan warga retardasi mental di Sidoharjo Jambon Ponorogo termasuk kategori cukup aktif.Masyarakat cukup aktif dalam kegiatan merencanakan program, melaksanakan program, dan mengevaluasi.Keterlibatan masyarakat dalam pelaksanaan model ini diwujudkan dalam berbagai bentuk bantuan. Bantuan yang 
paling dominan berupa tenaga yaitu mencapai $96,8 \%$, kemudian bantuan harta benda (15\%), pemikiran (9\%), dan uang (5\%). Ada beberapa faktor yang mempengaruhi partisipasi masyarakat dalam pelaksanaan model, dimulai dari rangking tertinggi yaitu; (1) adat gotong-royong yang masih membudaya yang dilandasi ikatan batin sesama warga desa akan hak tanggung jawab yang sama terhadap keselamatan dan kebahagiaan bersama di dalam masyarakat, (2) keyakinan bahwa warga retardasi mental bukan merupakan musibah tetapi ujian dari Tuhan, (3) perilaku tokoh masyarakat, tokoh agama, dan tokoh pemuda yang tidak sekadar memberi informasi tetapi juga teladan dalam menyikapi warga retardasi mental, (4) pengetahuan bahwa retardasi mental bukan penyakit dan orang retardasi mental masih memiliki potensi yang dapat diberdayakan, (5)Mata pencaharian hidup masyarakat yang mayoritas petani/buruh tani tidak menjadi kendala yang berarti untuk berpartisipasi walaupun berupa tenaga, dan (6) Jenis kelamin laki-laki dan perempuan relatif kecil pengaruhnya karena cara pandang masyarakat terhadap gender mulai bergeser dan memandang masalah warga retardasi mental menjadi tanggung jawab bersama.

Meskipun partisipasi masyarakat termasuk kategori cukup aktif namun tetap perlu ditingkatkan. Untuk itu disarankan pada pemerintah, para dermawan, dan para pihak yang peduli agar meningkatkan bantuan yang simultan terutama pemodalan, keterampilan, dan fasilitator pemberdayaan warga retardasi mental.

\section{Daftar Pustaka}

Aswar, S.(2011). Sikap Manusia, Teori dan Pengukurannya. Yogyakarta: Pustaka Pelajar.

Deviyanti, D. (2013). Studi Partisipasi Masyarakat Dalam Pembangunan Di Kelurahan Karangjati Kecamatan Balikpapan. Ejournal Administrasi Negara. Volume 1 Nomor 2. 2013:380-
394. From http:// ejournal.an.fisipunmul.org

Durand,M.V dan Barlow,D.H.(2007). Psikologi Abnormal. Terjemah Helly Prajitno Soetjipto dan Sri Mulyantini Soetjipto. Yogyakarta: Pustaka Pelajar.

Dusseldorp,D.B.W.N.(1981). Participation in Planned Development Influced by Goverments of Developing Local in Rural Areas. Wageningen: Wageningen University.

Hanif, M. dan Asri, DH.(2013). Perilaku dan Interaksi Sosial Warga Masyarakat Kampung Idiot Desa Sidoharjo dan Krebet Kecamatan Jambon Kabupaten Ponorogo dalam Counselia Jurnal Bimbingan dan Konseling Vol. 03 No. 2. November 2013.

Hanif, M. dan Afifah.(2015). Asanti Emotan, Alternatif Model Pemberdayaan Warga Retardasi Mental Kampung Sidoharjo Jambon Ponorogo.Madiun: Institut Press.

Hanif,M. dan Asri,DN.(2014). Meneropong Kampung Idiot, Perilaku Sosial terhadap Warga Retardasi Mental Sidoharjo dan Krebet. Madiun: Institut Press.

Hendriani, W dkk.(2006). Penerimaan Keluarga terhadap Individu yang Mengalami Retardasi Mental dalamJurnal Insan Vo. 8 No. 2 Agutus 2006. Surabaya: Universitas Airlangga.

Jarvis, Matt.2000. Teori-teori Psikologi, Pendekatan Modern untuk Memahami Perilaku, Perasaan \& Pikiran Manusia (terjemahan). Bandung: Nusa Media.

Maramis, W.F.(2005). Ilmu Kedokteran Jiwa. Surabaya: Airlangga University Press.

Mikkelsen, B. (2003) Metode Penelitian Partisipatoris dan Upaya-upaya Pemberdayaannya. Jakarta: Yayasan Obor Indonesia. 
gulawentah: Jurnal Studi Sosial

Volume 1 Nomor 1 Juli 2016, hal 1- 13

Avaliable online at http://e-journal.ikippgrimadiun.ac.id/index.php/gulawentah

Nevid,J.S., Rathus,SA, dan Green,B.(2005).

Psikologi Abnormal (terjemahan).

Jakarta: Erlangga.

Parson.(1994). The Integration of Social

Work Practice. California: Books/Cole.

Prijono dan Pranarka. 1996. Konsep-konsep

Pemberdayaan. Merriem Webster dan

Oxford English Dictionery.

Ritzer, G. (2012). Teori Sosiologi, dari Sosiologi Klasik sampai Perkembangan Terakhir Postmodern (terjemahan Saut Pasaribu dkk). Yogyakarta: Pustaka Pelajar.

Santrock,J.W.(2010). Psikologi Pendidikan. Jakarta: Kencana. 